Asian J Agric \& Biol. 2021(3).

\title{
Biochemical profile of albino rats with experimentally induced metabolic syndrome fed diet formulations of Cnidoscolus aconitifolius, Gongronema latifolium and Moringa oleifera leaves
}

\author{
Nene Orizu Uchendu ${ }^{1}$, Chiemekam Samuel Ezechukwu ${ }^{2 *}$, Lawrence Uchenna Sunday Ezeanyika ${ }^{1}$ \\ ${ }^{1}$ Department of Biochemistry, Faculty of Biological Sciences, University of Nigeria, Nsukka, Nigeria \\ ${ }^{2}$ Department of Zoology and Environmental Biology, Faculty of Biological Sciences, University of Nigeria, Nsukka, Nigeria
}

Received:

September 28, 2020

Accepted:

March 14, 2021

Online First:

April 02, 2021

Published:

July 07, 2021

\begin{abstract}
Metabolic syndrome (MS) has become a globally prevalent disease state, leading to mortality. Plants are a reservoir of compounds that have therapeutic potential and have been proven to be effective in management of a wide range of human and animal diseases. This study therefore, evaluated the effect of diet formulations of Cnidoscolus aconitifolius leaf (CAL), Gongronema latifolium leaf (GLL), and Moringa oleifera leaf (MOL) on some biochemical parameters of experimentally-induced MS in male albino rats. Forty-eight (48) adult male rats of 180-210 g body weight, were separated randomly into eight groups $(1-8)$ comprising six rats each. Group 1 was maintained on normal diet. MS was induced in Groups $2-8$ rats for eight weeks by high fat high carbohydrate (HFHC) diet. Afterwards, group 2 was fed normal rat diet (untreated), while groups 3 to 8 received diets formulated with GLL, CAL, MOL (100g per kg of diet) for eight weeks. Obesity indices, serum lipid profile, liver marker enzymes and antioxidant status were evaluated using standard methods. Significant $(p<0.05)$ decrease in body weight gain, total cholesterol and triacylglycerols of the treated rats were observed, while high density lipoprotein significantly $(\mathrm{p}<0.05)$ increased compared to the untreated group. Superoxide dismutase and catalase activities significantly $(\mathrm{p}<0.05)$ increased in the treatment groups. Treatment with the herbs showed mild Kupffer cell activation reversing periportal hepatitis induced by the HFHC diet. Results from the study indicate that CAL, GLL and MOL have therapeutic potentials that could be useful in managing components of MS.
\end{abstract}

Keywords: Antioxidant status, Lipid profile, Metabolic syndrome, High fat high Carbohydrate diet, Kupffer cells

\section{How to cite this:}

Uchendu NO, Ezechukwu CS and Ezeanyika LUS, 2021. Biochemical profile of albino rats with experimentally induced metabolic syndrome fed diet formulations of Cnidoscolus aconitifolius, Gongronema latifolium and Moringa oleifera leaves. Asian J. Agric. Biol. 2021(3): 202009505. DOI: https://doi.org/10.35495/ajab.2020.09.505 


\section{Introduction}

Metabolic syndrome (MS), has become a major public health concern worldwide, due to increasing urbanization with its attendant influence on individuals towards surplus energy intake and sedentary lifestyle. It involves multiple metabolic pathways, having insulin resistance and central obesity as its underlying risk factors with other disorders such as: microalbuminuria, dyslipidaemia and hypertension (Grundy et al., 2005; Mamikutty et al., 2014; Roche et al., 2005). Patients with MS have five times more chances of developing type 2 diabetes, and twice more chances of mortality from cardiovascular complications than in the absence of MS (Cardinali et al., 2013; Picchi et al., 2011). MS comprises a collection of abnormalities, which notably increase the risk of cardiovascular disease and type 2 diabetes with attendant mortality (Grundy et al., 2005; Wilson et al., 2005). Included in the abnormalities are: obesity, dyslipidemia, glucose intolerance, microalbuminuria, hypertension and glucose intolerance. The most widely accepted and clinically used definition of MS was given by International Diabetes Federation (Alberti et al., 2006) as central obesity occurring alongside any two of these: high fasting blood glucose, increased blood pressure, high triacyglycerol and low high-density lipoprotein (HDL) levels.

The global prevalence of MS ranges from $<10 \%$ to about $>80 \%$, varying based on the region, location (urban or rural area), composition of the population (gender, age, ethnicity, race), and the delineating parameters of the syndrome used in the study (Okafor, 2012). Available data show that MS affects $25 \%$ of the entire world population of adults. Differences in diet consumption, genetic factors, environment, and levels of physical activity contribute to the prevalence of MS and its various components (Bais et al., 2014). Managing MS clinically, is usually problematic as there is no singular measure or treatment for preventing or managing the syndrome holistically. Hence, successful treatment/management of MS is usually targeted at the individual components using such as lipid and glucose lowering agents, antihypertensive agents as well as insulin sensitizers (Nweje-Anyalowu et al., 2018; Okafor, 2012).

Medicinal plants have been widely used in treating individual components of MS. Increased use of herbal medicine has been documented as meeting the basic health care needs of up to $80 \%$ of those in rural areas of developing countries (Analike and Ahaneku, 2015).
In addition to the presence of biological activity which is exploited in managing several diseases, use of herbs present little or no adverse effects (Saxena et al., 2013). Gongronema latifolium leaves (GLL) and Moringa oleifera leaves (MOL) possess various nutritional and medicinal values and have been used widely in treatment of disorders associated with MS. Osuagwu et al. (2013) and Balogun et al. (2016) reported the presence of phenols, tannins, alkaloids, saponins, flavonoids, phytic acids and glycosides in GLL. The anti-hypertensive, antibacterial, antifungal, antimalarial, hypolipidaemic, hypoglycaemic and antioxidant effects of GLL extracts have been documented (Mensah et al., 2008). MOL reportedly possesses antimicrobial, antidiabetic, hepatoprotective, antiobesity, hypolipidaemic and anti-hypertensive activities (Bais et al., 2014; Onwe et al., 2015). Cnidoscolus aconitifolius leaves (CAL) are eaten as vegetable in South Eastern Nigerian and commonly called "hospital too far" because of its various traditional medicinal claims. Phytochemical investigation of CAL as previously reported showed the presence of phenols, saponins, alkaloids, tannins and phlobatannins (Mordi and Akanji, 2012). In view of these reported properties, this study investigated the effect of diet formulations of GLL, CAL and MOL on some biochemical parameters in experimentallyinduced MS using male albino rats.

\section{Material and Methods}

\section{Animals}

Forty-eight (48) adult male albino rats of 180-210 g body weight were obtained from the Faculty of Biological Sciences Animal House, University of Nigeria, Nsukka (UNN). The rats were maintained on a 12-hour dark-light cycle at room temperature; acclimatized for 14-days with ad libitum access to food (rat diet) and water. Ethical approval for the study regarding the use of experimental animals was obtained from the Ethics and Biosafety Committee of the Faculty of Biological Sciences, UNN with reference number UNN/FBS/EC/1028.

\section{Collection, identification and processing of plant materials}

Leaf samples of Gongronema latifolium and Moringa oleifera were obtained from Ogige Market and Obukpa respectively, both in Nsukka; while Cnidoscolus aconitifolius was collected from a 
vegetable garden in UNN. The plants were identified and authenticated by Mr. Alfred Ozioko, a taxonomist at the Bioresources Development and Conservation Programme (BDCP) Research Centre, Nsukka, Enugu State. The plant materials were air-dried, pulverized and packaged in air-tight-polyethene bags and stored at room temperature before use.

\section{Acute toxicity and lethality}

Testing the plant leaves for acute toxicity was done using a modification of Lorke's method (Lorke, 1983). A total of 16 mice weighing 18 - $28 \mathrm{~g}$ were used. First, nine mice separated into three groups of three per group were orally given 10,100 , and $1000 \mathrm{mg} / \mathrm{kg}$ body weight respectively of the plant leaves in solution. The mice were observed closely for $24 \mathrm{~h}$ for any abnormal behaviour or lethality. Subsequently, higher doses of 1500,2900 , and $5000 \mathrm{mg}$ extract $/ \mathrm{kg}$ body weight were respectively given orally to three groups of two mice each for the 1500- and 2900- doses and three mice for $5000 \mathrm{mg}$ extract/ $\mathrm{kg}$ body weight and observed for 24 $\mathrm{h}$ for any abnormal behaviour or death.

\section{Induction of metabolic syndrome}

To induce MS, high-fat high-carbohydrate (HFHC) diet, made up of high fat diet and $20 \%$ fructose drinking water (FDW) was fed the experimental animals for eight (8) weeks. The high fat diet formulation method was adapted from (Picchi et al., 2011) consisting of: fat $-500 \mathrm{~g} / \mathrm{kg}$, protein $-250 \mathrm{~g} / \mathrm{kg}$, carbohydrate $-200 \mathrm{~g} / \mathrm{kg}$, fibre $-40 \mathrm{~g} / \mathrm{kg}$, vitamin and mineral mix $-10 \mathrm{~g} / \mathrm{kg}$. FDW (20 g of fructose in $100 \mathrm{ml}$ of tap water) was freshly prepared at two-day intervals (Sánchez-Lozada et al., 2007; Shahraki et al., 2011) and administered ad libitum.

\section{Formulation and administration of rat diets}

Cnidoscolus aconitifolius leaves (CAL), Gongronema latifolium leaves (GLL) and Moringa oleifera leaves (MOL) were used in the formulation of rat diets according to Table 1 below. The plant leaves made up $10 \%(100 \mathrm{~g}$ per $\mathrm{kg})$ of the diet formulation for each group (Table 1). After the establishment of MS, rats were separated into eight groups with six rats in each group and fed the group specific diets for eight (8) weeks as follows:

Group 1: Commercial rat feed and tap water-Normal control

Group 2: MS rats fed commercial rat feed and tap water - Untreated control

Group 3: MS rats fed diet with CAL and tap water
Group 4: MS rats fed diet with GLL and tap water Group 5: MS rats fed diet with MOL and tap water Group 6: MS rats fed with combined CAL and GLL (1:1) diet and tap water

Group 7: MS rats fed with combined GLL and MOL (1:1) diet and tap water

Group 8: MS rats fed with combined CAL and MOL (1:1) diet and tap water

\section{Samples collection}

At the end of treatment duration, the animals were sacrificed after being anaesthetized using chloroform. Blood samples were drawn via cardiac puncture into non-heparinized sample tubes, allowed to clot and centrifuged at 4,000 rpm for $10 \mathrm{~min}$. The serum (supernatant) was collected and stored at $-20{ }^{\circ} \mathrm{C}$ for testing the various biochemical parameters. The liver of the rats was carefully excised, weighed and prepared for histopathological sectioning.

Table-1. Preparation of group-specific diet

\begin{tabular}{|l|c|c|}
\hline \multicolumn{1}{|c|}{ Class of food } & Source & Quantity $(\mathbf{g} / \mathbf{k g})$ \\
\hline Carbohydrate & Maize & 500 \\
\hline Protein & $\begin{array}{c}\text { Processed Soya bean } \\
\text { powder }\end{array}$ & 250 \\
\hline Fat & Beef tallow & 100 \\
\hline Fibre & Husk/chaff from cereals & 40 \\
\hline Vitamin-Mineral mix & Commercially procured & 10 \\
\hline Herbs & Plant leaves & 100 \\
\hline Energy value $(\mathrm{kcal} / \mathrm{kg})$ & & 4,620 \\
\hline
\end{tabular}

\section{Measurement of obesity indices}

Body weight of the rats was taken weekly using electronic scale. Body mass index (BMI) of the rats was taken as ratio of weight $(\mathrm{g})$ and length $(\mathrm{cm})$ of the rats - measured from the nasal to the anal region (Poudyal et al., 2010). The distance round the anterior abdomen was taken as abdominal circumference (AC) using a measuring tape (Mamikutty et al., 2014). The rats were anaesthetized using diethyl ether inhalation before measurements were taken. (Poudyal et al., 2010).

\section{Determination of serum lipid profile}

The serum total cholesterol (TC), high-density lipoprotein cholesterol (HDL-C) and triacylglycerol (TAG) were determined using standard methods Trinder (1969). 


\section{Liver function tests}

Aspartate aminotransferase (AST) and Alanine aminotransferase (ALT) activities were determined according to Reitman and Frankel (1957). Alkaline phosphatase (ALP) and total protein levels were obtained following the method of Tietz (1995) while albumin was determined as described by Doumas et al. (1997). The methods were as outlined in the assay kits leaflets.

\section{Oxidative stress index and antioxidant enzymes activities}

Estimation of malondialdehyde (MDA) levels was carried out as described by Buege and Aust (1978). Superoxide dismutase (SOD) activity was estimated following Misra and Fridovich (1972), while catalase (CAT) activity levels were obtained according to Takahara et al. (1960).

\section{Histopathology}

The preparation of liver for histopathological examination was done according to Drury et al. (1967). A thin section of about 1-2 cm of the excised liver tissues was fixed in $10 \%$ formalin solution and incubated at $25^{\circ} \mathrm{C}$ for 24 hours to ensure proper fixing. The tissue samples were dehydrated in ethanol and cleared using an automated tissue processor. Afterwards the tissues were infiltrated with paraffin wax at 50 to $52^{\circ} \mathrm{C}$, embedded into blocks, trimmed, sectioned using a microtome, mounted on clean albuminized slides, stained with haematoxylin and viewed at x400 magnification.

\section{Statistical analysis}

Statistical analysis of all data was performed using the software IBM SPSS Statistics 23. One-way ANOVA (analysis of variance) was used to test for significant differences at $\mathrm{p}<0.05$ while Duncan post hoc test was applied to separate means into homogenous subsets. Data is presented as mean $\pm \mathrm{SD}$ (standard deviation).

\section{Results}

\section{Acute toxicity}

Twenty four-hour acute toxicity test of G. latifolium, $C$. aconitifolius and $M$. oleifera leaves on mice resulted in no death or observable indications of toxicity to $5000 \mathrm{mg} / \mathrm{kg}$. No abnormal behaviours indicative of toxicity were observed in the mice within 24 hours after treatment.

Effect of $C$. aconitifolius, $G$. latifolium and $M$. oleifera-based diets on obesity indices of rats with experimentally-induced metabolic syndrome

The effect of diet formulations of $C$. aconitifolius, $G$. latifolium and $M$. oleifera on body weight, BMI and $\mathrm{AC}$ of rats with experimentally induced metabolic syndrome is shown in Tables 2, 3 and 4 respectively. Comparing with the untreated control, the rats in the treatment groups, fed the different diet formulations, had significantly $(\mathrm{p}<0.05)$ reduced body weights (Table 2). The BMI of the diet-fed rats was significantly $(p<0.05)$ less than that of the normal control but no different $(\mathrm{p}>0.05)$ from untreated control (Table 3). Although there was not any statistical difference $(\mathrm{p}>0.05)$ in AC of the treated rats compared with group 2 (untreated control), it was observed that the rats administered single herbs had slightly lower AC than the untreated control while the rats administered combined herbs had slightly higher (Table 4).

Table-2. Effect of C. aconitifolius, G. latifolium and $M$. oleifera-based diets on body weight of rats with experimentally-induced metabolic syndrome

\begin{tabular}{|l|c|c|c|}
\hline \multicolumn{1}{|c|}{ Group } & $\begin{array}{c}\text { Initial Body } \\
\text { Weight }(\mathbf{g})\end{array}$ & $\begin{array}{c}\text { Final Body Wt } \\
(\mathbf{g})\end{array}$ & $\begin{array}{c}\text { Body Wt Gain } \\
(\mathbf{g})\end{array}$ \\
\hline 1. Normal & $244.66 \pm 10.50^{\mathrm{a}}$ & $301.66 \pm 12.58^{\mathrm{a}}$ & $57.00 \pm 2.64^{\mathrm{a}}$ \\
\hline 2. Untreated & $282.66 \pm 7.02^{\mathrm{b}}$ & $381.66 \pm 2.88^{\mathrm{c}}$ & $99.00 \pm 9.53^{\mathrm{b}}$ \\
\hline 3. CAL & $290.00 \pm 4.00^{\mathrm{c}}$ & $350.33 \pm 2.51^{\mathrm{b}}$ & $60.33 \pm 3.78^{\mathrm{a}}$ \\
\hline 4. GLL & $276.66 \pm 6.65^{\mathrm{b}}$ & $334.33 \pm 12.09^{\mathrm{b}}$ & $57.66 \pm 8.62^{\mathrm{a}}$ \\
\hline 5. MOL & $274.00 \pm 12.16^{\mathrm{b}}$ & $334.33 \pm 12.09^{\mathrm{b}}$ & $60.33 \pm 2.51^{\mathrm{a}}$ \\
\hline 6. CAL + GLL & $293.33 \pm 3.21^{\mathrm{c}}$ & $356.66 \pm 10.40^{\mathrm{b}}$ & $63.33 \pm 8.08^{\mathrm{a}}$ \\
\hline 7. GLL + MOL & $283.66 \pm 7.23^{\mathrm{b}}$ & $346.67 \pm 5.68^{\mathrm{b}}$ & $63.00 \pm 2.00^{\mathrm{a}}$ \\
\hline 8. CAL + MOL & $282.00 \pm 6.08^{\mathrm{b}}$ & $341.67 \pm 33.29^{\mathrm{b}}$ & $59.66 \pm 22.36^{\mathrm{a}}$ \\
\hline
\end{tabular}

$\mathrm{n}=3$. Values are mean $\pm \mathrm{SD}$

values with different alphabet superscripts in a column are statistically different at $\mathrm{p}<0.05$ 
Table-3. Effect of C. aconitifolius, G. latifolium and $M$. oleifera-based diets on body mass index (BMI) of rats with experimentally-induced metabolic syndrome

\begin{tabular}{|l|c|c|c|}
\hline \multicolumn{1}{|c|}{ Group } & $\begin{array}{c}\text { Initial BMI } \\
\left(\mathbf{g} / \mathbf{c m}^{\mathbf{2}}\right)\end{array}$ & $\begin{array}{c}\text { Final BMI } \\
\left(\mathbf{g} / \mathbf{c m}^{2}\right)\end{array}$ & $\begin{array}{c}\text { BMI Gain } \\
(\mathbf{g})\end{array}$ \\
\hline 1. Normal & $0.49 \pm 0.03^{\mathrm{a}}$ & $0.62 \pm 0.08^{\mathrm{b}}$ & $0.13 \pm 0.06^{\mathrm{b}}$ \\
\hline 2. Untreated & $0.53 \pm 0.01^{\mathrm{b}}$ & $0.59 \pm 0.02^{\mathrm{a}}$ & $0.06 \pm 0.04^{\mathrm{a}}$ \\
\hline 3. CAL & $0.52 \pm 0.02^{\mathrm{b}}$ & $0.56 \pm 0.01^{\mathrm{a}}$ & $0.04 \pm 0.02^{\mathrm{a}}$ \\
\hline 4. GLL & $0.50 \pm 0.00^{\mathrm{b}}$ & $0.53 \pm 0.02^{\mathrm{a}}$ & $0.03 \pm 0.01^{\mathrm{a}}$ \\
\hline 5. MOL & $0.51 \pm 0.02^{\mathrm{b}}$ & $0.53 \pm 0.01^{\mathrm{a}}$ & $0.02 \pm 0.01^{\mathrm{a}}$ \\
\hline 6. CAL + GLL & $0.51 \pm 0.01^{\mathrm{b}}$ & $0.58 \pm 0.04^{\mathrm{a}}$ & $0.07 \pm 0.03^{\mathrm{a}}$ \\
\hline 7. GLL + MOL $^{\mathrm{a}}$ & $0.49 \pm 0.01^{\mathrm{a}}$ & $0.54 \pm 0.01^{\mathrm{a}}$ & $0.04 \pm 0.02^{\mathrm{a}}$ \\
\hline 8. CAL +MOL & $0.51 \pm 0.01^{\mathrm{b}}$ & $0.56 \pm 0.01^{\mathrm{a}}$ & $0.05 \pm 0.01^{\mathrm{a}}$ \\
\hline
\end{tabular}

$\mathrm{n}=3$. Values are mean $\pm \mathrm{SD}$

Values with different alphabet superscripts in a column are statistically different at $\mathrm{p}<0.05$

Table-4. Effect of C. aconitifolius, G. latifolium and $M$. oleifera-based diets on abdominal circumference (AC) of rats with experimentallyinduced metabolic syndrome

\begin{tabular}{|l|c|c|c|}
\hline \multicolumn{1}{|c|}{ Group } & $\begin{array}{c}\text { Initial AC } \\
(\mathbf{c m})\end{array}$ & $\begin{array}{c}\text { Final AC } \\
(\mathbf{c m})\end{array}$ & $\begin{array}{c}\text { AC Gain } \\
(\mathbf{c m})\end{array}$ \\
\hline 1. Normal & $13.60 \pm 0.52^{\mathrm{a}}$ & $14.60 \pm 0.36^{\mathrm{a}}$ & $1.00 \pm 0.30^{\mathrm{a}}$ \\
\hline 2. Untreated & $15.26 \pm 0.46^{\mathrm{b}}$ & $16.46 \pm 0.25^{\mathrm{b}}$ & $1.20 \pm 0.50^{\mathrm{a}}$ \\
\hline 3. CAL & $15.90 \pm 0.17^{\mathrm{b}}$ & $16.36 \pm 0.32^{\mathrm{b}}$ & $0.46 \pm 0.15^{\mathrm{a}}$ \\
\hline 4. GLL & $15.10 \pm 0.17^{\mathrm{b}}$ & $16.06 \pm 0.11^{\mathrm{b}}$ & $0.96 \pm 0.25^{\mathrm{a}}$ \\
\hline 5. MOL & $15.86 \pm 0.23^{\mathrm{b}}$ & $16.28 \pm 0.36^{\mathrm{b}}$ & $0.42 \pm 0.30^{\mathrm{a}}$ \\
\hline 6. CAL + GLL & $16.40 \pm 0.52^{\mathrm{b}}$ & $17.40 \pm 0.79^{\mathrm{b}}$ & $1.00 \pm 0.88^{\mathrm{a}}$ \\
\hline 7. GLL +MOL & $16.16 \pm 0.28^{\mathrm{b}}$ & $16.55 \pm 0.21^{\mathrm{b}}$ & $0.38 \pm 0.07^{\mathrm{a}}$ \\
\hline 8. CAL +MOL & $16.60 \pm 0.05^{\mathrm{b}}$ & $17.20 \pm 0.72^{\mathrm{b}}$ & $1.20 \pm 0.72^{\mathrm{a}}$ \\
\hline
\end{tabular}

$\mathrm{n}=3$. Values are mean $\pm \mathrm{SD}$

values with different alphabet superscripts in a column are statistically different at $\mathrm{p}<0.05$

Effect of $C$. aconitifolius, G. latifolium and $M$. oleifera-based diets on serum lipid profile of rats with experimentally-induced metabolic syndrome The rats treated GLL, MOL, CAL + GLL, GLL + MOL, and CAL + MOL had a significantly lower ( $\mathrm{p}<$ 0.05) mean total cholesterol (TC) concentrations compared with group 2 - untreated control (Table 5). TC of the rats treated with MOL and CAL + GLL were significantly less $(\mathrm{p}<0.05)$ than that of the normal control (group 1). TAG levels in all the treated except for the CAL-treated were significantly less $(\mathrm{p}<0.05)$ than that of group 2 (untreated control). All the treatment groups had TAG levels significantly decreased $(\mathrm{p}<0.05)$ in comparison with the group 1 (normal control) rats. Mean HDL-C levels of rats administered CAL, GLL + MOL and CAL + MOL were significantly higher $(\mathrm{p}<0.05)$ than in group 2 untreated control.

Table-5. Effect of C. aconitifolius, G. latifolium and M. oleifera-based diets on lipid profile of rats with experimentally-induced metabolic syndrome

\begin{tabular}{|l|c|c|c|}
\hline \multicolumn{1}{|c|}{ Group } & TC $(\mathbf{m g} / \mathbf{d l})$ & TAG $(\mathbf{m g} / \mathbf{d l})$ & HDL-C $(\mathbf{m g} / \mathbf{d l})$ \\
\hline 1. Normal & $133.33 \pm 13.33^{\mathrm{b}, \mathrm{c}}$ & $120.27 \pm 9.74^{\mathrm{d}}$ & $90.40 \pm 13.80^{\mathrm{b}}$ \\
\hline 2. Untreated & $144.00 \pm 20.13^{\mathrm{c}, \mathrm{d}}$ & $101.73 \pm 10.13^{\mathrm{c}}$ & $90.40 \pm 5.2^{\mathrm{b}}$ \\
\hline 3. CAL & $162.66 \pm 14.84^{\mathrm{d}, \mathrm{e}}$ & $102.84 \pm 1.01^{\mathrm{c}}$ & $141.62 \pm 21.09^{\mathrm{c}}$ \\
\hline 4. GLL & $114.66 \pm 7.05^{\mathrm{a}, \mathrm{b}}$ & $89.82 \pm 10.13^{\mathrm{a}, \mathrm{b}}$ & $102.45 \pm 13.13^{\mathrm{b}}$ \\
\hline 5. MOL & $96.00 \pm 4.61^{\mathrm{a}}$ & $94.45 \pm 10.70^{\mathrm{a}, \mathrm{b}}$ & $51.22 \pm 3.01^{\mathrm{a}}$ \\
\hline 6. CAL+GLL & $82.66 \pm 5.33^{\mathrm{a}}$ & $70.62 \pm 0.76^{\mathrm{a}}$ & $102.45 \pm 6.02^{\mathrm{b}}$ \\
\hline 7. GLL+MOL & $136.00 \pm 16.65^{\mathrm{b}, \mathrm{c}}$ & $76.57 \pm 4.50^{\mathrm{a}}$ & $117.52 \pm 13.80^{\mathrm{c}}$ \\
\hline 8. CAL+MOL $^{\mathrm{C}}$ & $122.66 \pm 11.62^{\mathrm{a}, \mathrm{b}}$ & $95.77 \pm 10.73^{\mathrm{a}, \mathrm{b}}$ & $180.80 \pm 9.04^{\mathrm{c}}$ \\
\hline
\end{tabular}

$\mathrm{n}=3$. Values are mean $\pm \mathrm{SD}$

Values with different alphabet superscripts in a column are statistically different at $p<0.05$

Effect of $C$. aconitifolius, $G$. latifolium and $M$. oleifera-based diets on liver function markers of rats with experimentally-induced metabolic syndrome

Aspartate aminotransferase (AST) activity was observed to be significantly higher $(\mathrm{p}<0.05)$ in rats given single herb diets (CAL, GLL, MOL), while that of rats treated with herbs in combination (CAL + GLL, GLL + MOL, CAL + MOL) was not significantly different compared with untreated control. No significant changes were observed in the alanine aminotransferase (ALT) activity of all the treatment groups compared with the untreated ( $p>0.05)$. Alkaline phosphatase (ALP) activity showed it was significantly higher $(p<0.05)$ in the treatment groups than in the untreated. Total protein of the treated rats was not significantly changed compared with that of group 2 - untreated $(\mathrm{p}>0.05)$. Albumin concentration was significantly lowered $(\mathrm{p}<0.05)$ in rats that were given CAL, CAL + GLL, GLL + MOL and CAL + MOL in comparison with the controls (Table 6). 
Uchendu Nene Orizu et al.

Table-6. Effect of $C$. aconitifolius, G. latifolium and M. oleifera-based diets on liver function markers of rats with experimentally-induced metabolic syndrome

\begin{tabular}{|l|c|c|c|c|c|}
\hline Group & AST $(\mathbf{U} / \mathbf{L})$ & ALT $(\mathbf{U} / \mathbf{L})$ & ALP $(\mathbf{U} / \mathbf{L})$ & Total Protein $(\mathbf{g} / \mathbf{d l})$ & Albumin $(\mathbf{g} / \mathbf{d l})$ \\
\hline 1. Normal & $19.89 \pm 1.99^{\mathrm{a}}$ & $11.53 \pm 3.15^{\mathrm{a}}$ & $7.95 \pm 0.98^{\mathrm{b}, \mathrm{c}}$ & $3.02 \pm 0.70^{\mathrm{a}, \mathrm{b}}$ & $2.57 \pm 0.33^{\mathrm{b}}$ \\
\hline 2. Untreated & $20.21 \pm 2.00^{\mathrm{a}}$ & $8.48 \pm 0.16^{\mathrm{a}}$ & $3.78 \pm 0.16^{\mathrm{a}}$ & $3.68 \pm 0.81^{\mathrm{a}, \mathrm{b}}$ & $3.02 \pm 0.08^{\mathrm{b}}$ \\
\hline 3. CAL & $34.53 \pm 3.80^{\mathrm{b}, \mathrm{c}}$ & $20.50 \pm 3.08^{\mathrm{a}}$ & $5.96 \pm 0.59^{\mathrm{a}, \mathrm{b}}$ & $3.48 \pm 0.08^{\mathrm{a}, \mathrm{b}}$ & $2.49 \pm 0.43^{\mathrm{a}}$ \\
\hline 4. GLL & $33.73 \pm 3.72^{\mathrm{b}, \mathrm{c}}$ & $10.24 \pm 0.64^{\mathrm{a}}$ & $6.06 \pm 0.43^{\mathrm{a}, \mathrm{b}}$ & $3.27 \pm 0.50^{\mathrm{a}, \mathrm{b}}$ & $3.07 \pm 0.76^{\mathrm{b}, \mathrm{c}}$ \\
\hline 5. MOL & $37.44 \pm 0.36^{\mathrm{c}}$ & $14.75 \pm 4.22^{\mathrm{a}}$ & $8.90 \pm 1.98^{\mathrm{c}}$ & $4.27 \pm 0.75^{\mathrm{a}, \mathrm{b}}$ & $3.07 \pm 0.02^{\mathrm{b}, \mathrm{c}}$ \\
\hline 6. CAL+GLL & $20.75 \pm 2.81^{\mathrm{a}}$ & $15.19 \pm 4.07^{\mathrm{a}}$ & $9.09 \pm 0.28^{\mathrm{c}}$ & $4.18 \pm 0.65^{\mathrm{a}, \mathrm{b}}$ & $2.33 \pm 0.44^{\mathrm{a}}$ \\
\hline 7. GLL+MOL & $22.21 \pm 3.18^{\mathrm{a}}$ & $13.18 \pm 4.27^{\mathrm{a}}$ & $9.46 \pm 0.99^{\mathrm{c}}$ & $2.92 \pm 0.43^{\mathrm{a}, \mathrm{b}}$ & $1.90 \pm 0.53^{\mathrm{a}}$ \\
\hline 8. CAL+MOL & $25.98 \pm 0.67^{\mathrm{a}, \mathrm{b}}$ & $20.16 \pm 3.47^{\mathrm{a}}$ & $8.61 \pm 0.84^{\mathrm{c}}$ & $4.85 \pm 2.09^{\mathrm{b}}$ & $1.35 \pm 0.16^{\mathrm{a}}$ \\
\hline
\end{tabular}

$\mathrm{n}=3$. Values are mean $\pm \mathrm{SD}$

values with different alphabet superscripts in a column are statistically different at $p<0.05$

Effect of $C$. aconitifolius, G. latifolium and $M$. oleifera-based diets on serum Malondialdehyde (MDA) and antioxidant enzymes of rats with experimentally-induced metabolic syndrome

Observed MDA concentrations of all the test groups did not statistically differ $(\mathrm{p}>0.05)$ from the untreated. However, treatment with MOL, CAL + GLL, GLL + MOL and CAL + MOL significantly raised $(\mathrm{p}<0.05)$ SOD activity compared with the untreated. Significantly higher $(\mathrm{p}<0.05)$ catalase activity in all the treated groups was observed in comparison with the untreated, with the exception of the MOL- and CAL + GLL-treated groups (Table 7).

Table-7. Effect of $C$. aconitifolius, G. latifolium and $M$. oleifera-based diets on MDA and antioxidant enzymes of rats with experimentally-induced metabolic syndrome

\begin{tabular}{|l|c|c|c|}
\hline \multicolumn{1}{|c|}{ Group } & $\begin{array}{c}\text { MDA } \\
\text { (U/mg } \\
\text { protein) }\end{array}$ & $\begin{array}{c}\text { SOD } \\
\text { (IU/mg } \\
\text { protein) }\end{array}$ & $\begin{array}{c}\text { CAT } \\
\text { (IU/mg } \\
\text { protein) }\end{array}$ \\
\hline 1 Normal & $6.43 \pm 0.76^{\mathrm{a}}$ & $74.51 \pm 3.17^{\mathrm{a}, \mathrm{b}}$ & $0.66 \pm 0.10^{\mathrm{a}}$ \\
\hline 2 Untreated & $7.15 \pm 3.16^{\mathrm{a}}$ & $42.85 \pm 10.52^{\mathrm{a}}$ & $1.38 \pm 0.73^{\mathrm{a}, \mathrm{b}}$ \\
\hline 3 CAL & $6.63 \pm 2.47^{\mathrm{a}}$ & $56.97 \pm 12.75^{\mathrm{a}}$ & $2.54 \pm 0.06^{\mathrm{c}}$ \\
\hline $4 \mathrm{GLL}$ & $5.19 \pm 0.81^{\mathrm{a}}$ & $54.35 \pm 15.58^{\mathrm{a}}$ & $1.98 \pm 0.56^{\mathrm{b}, \mathrm{c}}$ \\
\hline 5 MOL & $6.96 \pm 4.68^{\mathrm{a}}$ & $101.24 \pm 13.99^{\mathrm{b}}$ & $1.10 \pm 0.32^{\mathrm{a}, \mathrm{b}}$ \\
\hline 6 CAL+GLL & $7.80 \pm 0.16^{\mathrm{a}}$ & $131.88 \pm 36.46^{\mathrm{b}}$ & $1.78 \pm 0.54^{\mathrm{b}}$ \\
\hline 7 GLL+MOL & $10.89 \pm 2.73^{\mathrm{a}}$ & $76.97 \pm 11.29^{\mathrm{a}, \mathrm{b}}$ & $2.47 \pm 0.68^{\mathrm{c}}$ \\
\hline 8 CAL+MOL & $11.88 \pm 5.05^{\mathrm{a}}$ & $131.16 \pm 37.19^{\mathrm{b}}$ & $2.28 \pm 0.64^{\mathrm{b}, \mathrm{c}}$ \\
\hline
\end{tabular}

$\mathrm{n}=3$. Values are mean $\pm \mathrm{SD}$

Values with different alphabet superscripts in a column are statistically different at $p<0.05$

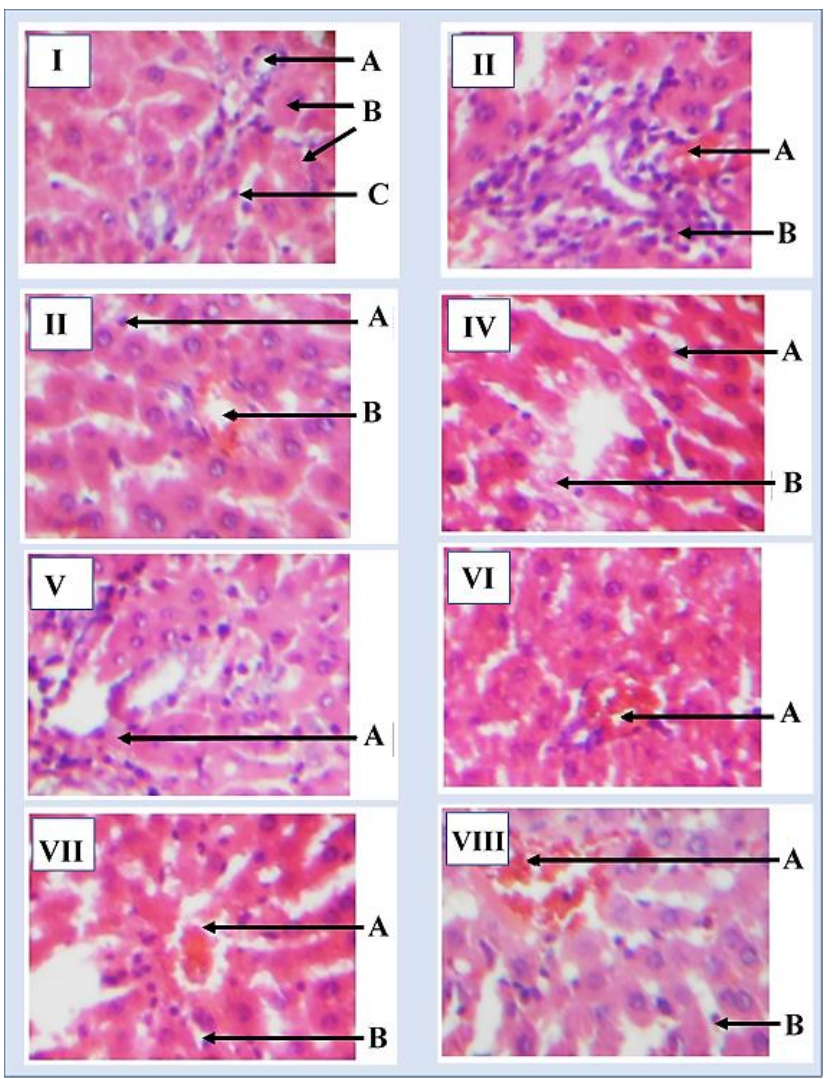

Figure-1. Liver histology of rats with experimentallyinduced metabolic syndrome (H\&E x 100)

Liver section photomicrographs of: I. normal control rats showing A-bile duct, B-hepatocytes and C-sinusoids; II. MS induced rats (untreated control) showing A-slight vascular congestion and B-periportal infiltration by chronic inflammatory cells; III. Rats induced and treated with CAL showing A-activated Kupffer cells and B-slight vascular congestion; IV. MS induced rats after treatment with GLL showing A-activated Kupffer cells and B-mild microvascular steatosis; V. MS induced rats treated with MOL showing A-normal liver architecture; VI. MS induced 
rats treated with CAL + GLL showing A-slight vascular congestion; VII. Rats induced and treated with GLL + MOL showing A-slight vascular congestion and B-activated Kupffer cells; VIII. MS induced rats following treatment with CAL + MOL showing A-slight vascular congestion and B-activated Kupffer cells.

Effect of $C$. aconitifolius, $G$. latifolium and $M$. oleifera-based diets on liver histology rats with experimentally-induced metabolic syndrome

The liver of rats induced with MS (especially the untreated control) showed slight vascular congestion and periportal infiltration of chronic inflammatory cells (periportal hepatitis) compared to normal control which showed normal hepatic architecture. However, presence of activated Kupffer cells was evident in the CAL, GLL, CAL + MOL and GLL + MOL groups, while treatment with MOL restored normal liver architecture (Figure 1).

\section{Discussion}

Metabolic syndrome (MS) manifests with obesity as one of its important risk factors. Thus, interventions that target body weight reduction are useful in management of MS. The study findings indicate that the diet formulations of $C$. aconitifolius, $G$. latifolium and $M$. oleifera had a weight reducing effect on the rats. Weight-reducing ability of plants has been attributed to their polyphenol constituents and exploited in prevention and management of many disease conditions including obesity and related ailments (Cory et al., 2018). Thus, the high polyphenol (flavonoid) content of $C$. aconitifolius, $G$. latifolium and $M$. oleifera could be associated with the body weight-limiting effect observed. This finding agrees with that of Bakr and Header (2014) who reported a marked decrease in body weight gain after the treatment of obese rats with aqueous extracts of green tea (Camellia sinensis), which is known to contain appreciable quantity of polyphenols.

Treatment of MS-induced rats with diets compounded with $M$. oleifera, $G$. latifolium and $C$. aconitifolius leaves brought about a significant decrease in serum lipids (TC and TAG) indicating the potential of these herbs to help decrease the incidence of cardiovascular diseases. This is in line with previous reports on the use of M. oleifera and G. latifolium leaf extracts in the management of hyperlipidaemia (Onwe et al., 2015) indicating that the herbs could decrease the formation of triacylglycerols in the liver whilst helping in the redistribution of cholesterol. Low concentration of HDL-cholesterol predisposes to cardiovascular disease. HDL has cardio-protective properties because it serves a crucial role in mopping up excess cholesterol from peripheral tissues by reverse cholesterol transport (Ademuyiwa et al., 2005). Increased TC levels in blood is a major risk factor for coronary diseases (Ademuyiwa et al., 2005). Dyslipidaemia, mainly described as high TAG/LDL and low HDL, is an abnormal concentration of blood lipid and one risk factor for atherosclerosis which often results in hypertension, diabetes mellitus and cardiovascular disease (Hyson et al., 2002; Onwe et al., 2015). The increase observed in HDL-C in the treatment groups is in line with the findings of Ugwu et al. (2010), who studied effect of diet incorporated with G. latifolium and Vernonia amygdalina leaves on blood lipids of rats. They reported a significant decrease of serum TC and TAG and a significant HDL-C increase. Flavonoids, tannins and saponins found in some plants are reported to have hypolipidaemic activities (Ezekwe and Obidoa, 2001). Diet preparations are helpful in preventing lipid disorders which may arise as a result of metabolic disorders (Cho et al., 2002). Two processes which maintain cholesterol homeostasis are its synthesis and absorption, catalyzed by HMG-Co-A reductase in the rate limiting step. Jain et al. (2010) reported a significant decrease of HMG-Co-A reductase activity by Moringa oleifera extract. The groups in this study treated with GLL and CAL + GLL had the best lipidlowering activities. As has been suggested (AhmadRaus et al., 2001), lipid-lowering activities might be associated with the high amounts of flavonoid and saponin contained in the studied plants. Also, the plants may possess anti-hypercholesterolaemic properties and act by preventing intestinal uptake of dietary cholesterol, preventing liver synthesis of cholesterol or by promoting its biliary secretion in faeces (Ahmad-Raus et al., 2001).

The liver enzymes AST, ALT and ALP are widespread in the tissues but are more concentrated in the liver, bone, intestine and placenta. In healthy liver, these enzymes are usually low. However, following tissue damage, changes occur in both function and membrane permeability leading to escape of enzymes from the cells (Ezeonwu and Dahiru, 2013). The liver enzymes did not reduce in the treatment groups fed diet formulations using the leaves of Moringa, Gongronema and Cnidoscolus. The possible explanation could be that the quantity of herbs used in 
the diet formulations could not offer hepatocellular repair or any therapeutic effect to the liver damage done by the chronic consumption of high fat high carbohydrate diet. This finding is in contrast with earlier reports on the hepatoprotective effect of these plants' extracts where Gongronema latifolium, Ocimum gratissimum and Moringa oleifera leaf extracts showed hepatoprotective effects in high fat diet-induced (Das et al., 2012) and acetaminopheninduced (Ezeonwu and Dahiru, 2013) liver damage in mice and rats respectively.

Over time, research has revealed that free radicals are predisposing factors to disease conditions such as atherosclerosis, diabetes and cardiovascular disease. Free radicals can arise in obese-prone subjects from $\beta$ adrenergic receptor activation, promoting lipolysis and consequent release of free fatty acids, which in turn produce more free radicals by uncoupling mitochondrial phosphorylation (Bhandari et al., 2011). These free radicals cause oxidative damage to cell membrane lipids and proteins as well as irreversible DNA modification, in all distorting the integrity of the cell (Flora, 2007). Oxidative stress is strongly associated with damage in the body caused by free radicals (Olusi, 2002). Treatment of MS rats with diets formulated with the leaves of $M$. oleifera, G. latifolium and $C$. aconitifolius individually, caused a slight reduction in serum MDA. However, Ahmed et al. (2014) reported that treatment with Moringa oleifera extract significantly $(\mathrm{p}<0.05)$ reduced serum MDA level in female albino rats. In our study, consumption of the plants (in combination) did not show a marked effect on MDA levels of the rats. This was rather not expected considering the high flavonoid contents of the plants. Flavonoids have several reported biological functions which include anti-inflammatory, antimicrobial and anti-tumor activities but their notable role is their ability to function as antioxidants thereby shielding the body from the debilitating actions of reactive oxygen species and free radicals. This antioxidant role is facilitated by the arrangement and composition of their chemical structure. We expected a synergistic effect resulting in marked reduction of MDA levels when the herbs were used as a combined therapy, however, this was not observed. The interaction of the varied bioactive components with each other and the anti-nutrients present in the plants may have either reduced the availability or inhibited the absorption of the particular antioxidant compounds needed.

In addition to lipid peroxidation, oxidative stress is characterized by the reduced antioxidant enzymes activities. These enzymes including CAT, SOD, GST, and GPx play active roles mopping up free radicals during oxidative stress conditions (Noeman et al., 2011). The synergistic antioxidant property of flavonoidal compounds in M. oleifera, G. latifolium and $C$. aconitifolius contributed to the raised SOD and catalase levels (Umar, 2012). Other studies have reported significant antioxidant property of some other plants on serum, kidney and liver SOD and catalase activities in high fat diet rat models (Umar, 2012), attributing the antioxidant properties of plants mainly to their phenolic constituents. Usoh and Akpan (2015) reported higher antioxidant activity of G. latifolium leaf used in combination with Ocimum gratissimum, pointing to a possible synergistic interaction of the bioactive constituents of these leaves.

The observed vascular congestion and inflammation in liver of rats following consumption of HFHC diet are characteristic of the metabolic disease state. Chronic inflammation, brought about in metabolic cells in response to surplus nutrients/ energy (Gregor and Hotamisligil, 2011), is seen in cases of obesity, insulin resistance, type 2 diabetes, and cardiovascular disease (Furuhashi et al., 2011). Treatment with combinations of the herbs mainly caused mild Kupffer cell activation, which is a compensatory response that serves to minimize cellular and organ damage in disease states (Dixon et al., 2013). The presence of slight vascular congestion in almost all the treatment groups suggests that the herbs did not fully repair or reverse the damage already done to the hepatocytes. This inference agrees with the results of the serum liver enzyme markers reported above. The observation of normal liver architecture in the MOL-group herein agrees with the findings of Bais et al. (2014) that methanol extract of $M$. oleifera leaf restored normal hepatocytes in obese rats.

\section{Conclusion}

The utilization of feed formulations of Cnidoscolus aconifolius, Gongronema latifolium and Moringa oleifera as treatment for rats with experimentally induced metabolic syndrome in this study showed reduction in metabolic and cardiovascular risks in terms of weight reduction, favourable lipid profile and increase in antioxidant enzymes (SOD and catalase) activities. Thus, the herbs have some therapeutic effects that could be exploited in the management of metabolic syndrome components. 
Disclaimer: None.

Conflict of Interest: None.

Source of Funding: None.

\section{References}

Ademuyiwa O, Ugbaja RN, Idumebor F and Adebawo $\mathrm{O}, 2005$. Plasma lipid profiles and risk of cardiovascular disease in occupational lead exposure in Abeokuta, Nigeria. Lipids Health Dis. 4:19.

Ahmad-Raus RR, Abdul-Latif ES and Mohammad JJ, 2001. Lowering of lipid composition in aorta of guinea pigs by Curcuma domestica. BMC Complement. Altern. Med. 1:6.

Ahmed HH, Metwally FM, Rashad H, Zaazaa AM, Ezzat SM and Salama MM, 2014. Moringa oleifera offers a multi-mechanistic approach for management of obesity in rats. Int. J. Pharm. Sci. Rev. Res. 29(2): 98-106.

Alberti KGMM, Zimmet P and Shaw J, 2006. Metabolic syndrome-a new world-wide definition. A consensus statement from the International Diabetes Federation. Diabet. Med. 23:469-480.

Analike R and Ahaneku J, 2015. Effects of Gongronema latifolium on blood lipids, lipoproteins and glucose values in adult Nigerians. Int. J. Res. Med. Sci. 3:891.

Bais S, Singh GS and Sharma R, 2014. Antiobesity and hypolipidemic activity of Moringa oleifera leaves against high fat diet-induced obesity in rats. Adv. Biol. 2014:1-9.

Bakr ESH and Header EA, 2014. Effect of aqueous extract of green tea (Camellia Sinensis L.) on obesity and liver status in experimental rats. Int. J. Pure Appl. Sci. Technol. 21:53-63.

Balogun E, Besong E, Obimma N and Mbamalu A, 2016. Gongronema Latifolium: a phytochemical, nutritional and pharmacological review. J. Physiol. Pharmacol. Adv. 6:811.

Bhandari U, Kumar V, Khanna N and Panda BP, 2011. The effect of high-fat diet-induced obesity on cardiovascular toxicity in wistar albino rats. Hum. Exp. Toxicol. 30:1313-1321.

Buege JA and Aust SD, 1978. Microsomal lipid peroxidation. Methods Enzymol. 52:302-310.

Cardinali DP, Scacchi Bernasconi PA, Reynoso R, Reyes Toso CF and Scacchi P, 2013. Melatonin may curtail the metabolic syndrome: studies on initial and fully established fructose-induced metabolic syndrome in rats. Int. J. Mol. Sci.
14:2502-2514.

Cho SY, Park JY, Park EM, Choi MS, Lee MK, Jeon SM, Jang MK, Kim MJ and Park YB, 2002. Alternation of hepatic antioxidant enzyme activities and lipid profile in streptozotocininduced diabetic rats by supplementation of dandelion water extract. Clin. Chim. Acta 317:109-117.

Cory H, Passarelli S, Szeto J, Tamez M and Mattei J, 2018. The role of polyphenols in human health and food systems: a mini-review. Front. Nutr. 5:87

Das N, Skider K, Ghosh S, Fromenty B and Dey S, 2012. Moringa oleifera Lam. leaf extract prevents early injury and restores antioxidant status in mice fed with high-fat diet. Indian J. Exp. Biol. 50(6): $404-412$.

Dixon LJ, Barnes M, Tang H, Pritchard MT and Nagy LE, 2013. Kupffer cells in the liver. Compr. Physiol. 3:785-797.

Doumas BT, Watson WA and Biggs HG, 1997. Albumin standards and the measurement of serum albumin with bromcresol green. Clin. Chim. Acta 258:21-30.

Drury RA, Wallington A and Cameroun SR, 1967. Carlleton's Histological Techniques. Oxford University Press, New York.

Ezekwe CI and Obidoa O, 2001. Biochemical effect of Vernonia amygdalina on rats liver microsomes. Niger J. Biochem. Mol. Biol. 16:1745-1798.

Ezeonwu VU and Dahiru D, 2013. Protective effect of bi-herbal formulation of Ocimum gratissimum and Gongronema latifolium aqueous leaf extracts on acetaminophen-induced hepato-nephrotoxicity in rats. Am. J. Biochem. 3(1):18-23.

Flora SJS, 2007. Role of free radicals and antioxidants in health and disease. Cell Mol. Biol. 53:1-2.

Furuhashi M, Ishimura S, Ota H and Miura T, 2011. Lipid chaperones and metabolic inflammation. Int. J. Inflam. 2011:1-12.

Gregor MF and Hotamisligil GS, 2011. Inflammatory mechanisms in obesity. Annu. Rev. Immunol. 29:415-445.

Grundy SM, Cleeman JI, Daniels SR, Donato KA, Eckel RH, Franklin BA, Gordon DJ, Krauss RM, Savage PJ, Smith SC, Spertus JA and Costa F, 2005. Diagnosis and management of the metabolic syndrome: an American Heart Association/National Heart, Lung, and Blood Institute scientific statement. Circulation 112:2735-2752. 
Hyson DA, Schneeman BO and Davis PA, 2002. Almonds and almond oil have similar effects on plasma lipids and LDL oxidation in healthy men and women. J. Nutr. 132:703-707.

Jain PG, Patil SD, Haswani NG, Girase MV and Surana SJ, 2010. Hypolipidemic activity of Moringa oleifera Lam., Moringaceae, on high fat diet induced hyperlipidemia in albino rats. Brazilian J. Pharmacogn. 20:969-973.

Lorke D, 1983. A new approach to practical acute toxicity testing. Arch. Toxicol. 54:275-287.

Mamikutty N, Thent ZC, Sapri SR, Sahruddin NN, Mohd Yusof MR and Haji Suhaimi F, 2014. The establishment of metabolic syndrome model by induction of fructose drinking water in male wistar rats. Biomed. Res. Int. 2014.

Mensah JK, Okoli RI, Ohaju-Obodo JO and Eifediyi K, 2008. Phytochemical, nutritional and medical properties of some leafy vegetables consumed by Edo people of Nigeria. Afr. J. Biotechnol. 7:23042309.

Misra HP and Fridovich I, 1972. The role of superoxide anion in the autoxidation of epinephrine and a simple assay for superoxide dismutase. J. Biol. Chem. 247:3170-3175.

Mordi JC and Akanji MA, 2012. Phytochemical screening of the dried leaf extract of Cnidoscolus aconitifolius and associated changes in liver enzymes induced by its administration in Wistar rats. Curr. Res. J. Biol. Sci. 4:153-158.

Noeman SA, Hamooda HE and Baalash AA, 2011. Biochemical study of oxidative stress markers in the liver, kidney and heart of high fat diet induced obesity in rats. Diabetol. Metab. Syndr. 3:17.

Nweje-Anyalowu PC, Agatemor UM-M, Idakwoji PA and Iserhienrhien LO, 2018. Protective effects of methanolic extract of Cassia sieberena leaves against high-fat diet-induced metabolic syndrome in rats. World J. Pharm. Life Sci. 4:41-47.

Okafor C, 2012. The metabolic syndrome in Africa: current trends. Indian J. Endocrinol. Metab. 16:56.

Olusi SO, 2002. Obesity is an independent risk factor for plasma lipid peroxidation and depletion of erythrocyte cytoprotectic enzymes in humans. Int. J. Obes. 26:1159-1164.

Onwe PE, Folawiyo MA, Anyigor-Ogah CS, Uche JE, Balogun ME, Umahi G, Besong EE, Okorocha AE and Afoke AO, 2015. Extracts of Moringa oleifera a sure bet for hyperlipidemia management. IOSR J. Pharm. Biol. Sci. 10:28-32.
Osuagwu AN, Ekpo IA, Okpako EC, Otu P and Ottoho E, 2013. The biology, utilization and phytochemical composition of the fruits and leaves of Gongronema latifolium Benth. Agrotechnology 02:115

Picchi MG, de Mattos AM, Barbosa MR, Duarte CP, Gandini M de A, Portari GV and Jordão AA, 2011. A high-fat diet as a model of fatty liver disease in rats. Acta Cir. Bras. 26:25-30.

Poudyal H, Campbell F and Brown L, 2010. Olive leaf extract attenuates cardiac, hepatic, and metabolic changes in high carbohydrate- high fat-fed rats. J. Nutr. 140:946-953.

Reitman S and Frankel S, 1957. A colorimetric method for the determination of serum glutamic oxalacetic and glutamic pyruvic transaminases. Am. J. Clin. Pathol. 28:56-63.

Roche HM, Phillips C and Gibney MJ, 2005. The metabolic syndrome: the crossroads of diet and genetics. Proc. Nutr. Soc. 64:371-377.

Sánchez-Lozada LG, Tapia E, Jiménez A, Bautista P, Cristóbal M, Nepomuceno T, Soto V, ÁvilaCasado C, Nakagawa T, Johnson RJ, HerreraAcosta J and Franco M, 2007. Fructose-induced metabolic syndrome is associated with glomerular hypertension and renal microvascular damage in rats. Am. J. Physiol - Ren. Physiol. 292:F423-429.

Saxena M, Saxena J, Nema R, Singh D and Gupta A, 2013. Phytochemistry of medicinal plants. J. Pharmacogn. Phytochem. 1:168-182.

Shahraki MR, Harati M and Shahraki AR, 2011. Prevention of high fructose-induced metabolic syndrome in male wistar rats by aqueous extract of Tamarindus indica seed. Acta. Med. Iran. 49:277-283.

Takahara S, Hamilton HB, Neel J V, Kobara TY, Ogura $Y$ and Nishimura ET, 1960. Hypocatalasemia: a new genetic carrier state. J. Clin. Invest. 39:610-619.

Tietz NW, 1995. Clinical guide to laboratory tests, 2nd ed. W B Saunders Company. Philadelphia, USA.

Trinder P, 1969. Determination of glucose in blood using glucose oxidase with an alternative oxygen acceptor. Ann. Clin. Biochem. 6:24-27.

Ugwu C, Alumana E and Ezeanyika L, 2010. Comparative effects of the leaves of Gongronema latifolium and Vernonia amygdalina incorporated diets on the lipid profiles of rats. Biokemistri 21:59-65. 
Umar IA, 2012. The hypolipidemic and antioxidant actions of aqueous extracts of Ocimum basilicum and Ocimum suave in high fat fed rats. J. Med. Plants Res. 6:3501-3505.

Usoh IF and Akpan HD, 2015. Antioxidative efficacy of combined leaves extracts of Gongronema latifolium and Ocimum gratissimum on streptozotocin induced diabetic rats. Int. Invent. J. Med. Med. Sci. 2:88-95.

Wilson PWF, D'Agostino RB, Parise H, Sullivan L and Meigs JB, 2005. Metabolic syndrome as a precursor of cardiovascular disease and type 2 diabetes mellitus. Circulation 112:3066-3072.

\section{Contribution of Authors}

Uchendu NO: Carried out the laboratory experiments, statistical analysis, and drafting of the manuscript.

Ezechukwu CS: Guided the research, helped in statistical analysis and edited the manuscript Ezeanyika LUS: Conceptualized the study, guided and supervised the research 